\title{
Japanese imports of brazilian raw cotton in the second half of the 1930s: the beginning of significant japanese-brazilian trade and investment relations
}

Henri Delanghe

Katholieke Universiteit Leuven - Belgica

In 1935, a Japanese trade mission visited Brazil. The mission resulted in a significant increase in the value of Japanese-Brazilian trade. The value of Japanese exports to Brazil increased from $£ 246,852$ in 1935 to $£ 349,609$ in 1936 , and $£ 647,472$ in 1937. The value of Brazilian exports to Japan increased more significantly, from $£ 158,098$ in 1935 to $£ 1,683,333$ in 1936 , and $£ 2,122,106$ in 1937. (Table 1) Most of these Brazilian exports consisted of raw cotton. In 1938, Brazil sent 22.4 percent of its raw cotton to Japan, compared to only 1.3 percent in 1934. It thus accounted that year for 10.7 percent of Japan's raw cotton imports, compared to only 0.2 percent in 1934. (Table 2)

This paper asks why Japan started importing large quantities of Brazilian raw cotton in 1936. This was an interesting phenomenon. As the above mentioned figures demonstrate, it was not unimportant from a purely quantitative point of view, whether one looks at it from the Brazilian or the Japanese side. But it also constituted the starting point of significant Japanese-Brazilian trade and investment relations. Japan and Brazil had signed a Treaty of Amity, Commerce and Navigation in 1895. But, for forty years, the exchange between the two countries remained limited to Japanese emigration to Brazil. The 1935 Japanese trade mission to Brazil changed this. Bilateral trade became important before the Second World War and picked up quickly after it, reaching now a level of US \$ six billion annually Also as a result of that mission, Japanese firms undertook a number of trade-enhancing investments in Brazil. Inactive during the War, they nevertheless constituted a clear basis for a number of post-War booms of Japanese investment in Brazil - e.g. during the second half of the 1950s and in the early 1970s. The 
cumulative total of Japanese investment in Brazil has now exceeded US \$ ten billion.

Current literature has largely disregarded this sudden jump in Japanese-Brazilian trade largely centered around the increase of Japanese imports of Brazilian raw cotton in the second half of the 1930s. The few passing references to it are either too general or incorrect. Sometimes, political explanations have been suggested. The typical argument goes as follows. During the 1930s, Japan was dependent on the United States for an important part of its raw cotton imports. In the second half of the 1930s, tensions developed between Japan and the United States. Thus Japan wanted to reduce its dependence on the United States and replace American with Brazilian raw cotton.

There is some merit in this argument. It is true that the size and timing of the decrease in Japanese imports of American raw cotton broadly coincided with the size and timing of the increase in Japanese imports of Brazilian raw cotton. It is also true that during the second half of the 1930s the voices of japanese intellectuals expressing concern about geo-strategic control over textile and other natural resources grew much louder. ${ }^{2}$ But the said argument does not fit the reality that even as Japan reduced its imports of American raw cotton Japan's trade deficit with the United States remained very large. (Table 3) Nor does it fit the written evidence on the reasons for organizing the 1935 Japanese trade mission to Brazil. It thus seems that said argument is anachronistic. Japan started importing large quantities of Brazilian raw cotton in 1936. The Japanese trade mission to Brazil took place in 1935, and preparations for it mission started in 1934. To understand Japan's reasons for organizing the trade mission to Brazil and importing large quantities of Brazilian raw cotton, one has to study in the first place Japan's place in the world in 1934 - a time at which there were no significant Japanese - American tensions - not reason backwards from late - 1930s Japanese-American tensions.

Saito, 1983: 168:"Hirao's idea of replacing cotton from the United States with Brazilian cotton proved a success, for, apart from its one objective of helping Japanese immigrants in cotton production, Brazilian cotton was cheaper than the American product, and Japan was anxious to avoid dependence on the United States in view of the impending threat of war."

Nawa, 1936.

\section{I Henri Delanghe}


Table 1. Japanese-Brazilian trade, 1934-9 (British pounds)

\begin{tabular}{lccc}
\hline Yean & Japanese Imports & Japanese Exports & Exports-Imports \\
\hline 1934 & 105,202 & 169,465 & 64,263 \\
1935 & 158,098 & 246,852 & $\mathbf{8 8 , 7 5 4}$ \\
1936 & $1,683,333$ & 349,609 & $-1,333,724$ \\
1937 & $2,122,106$ & 647,472 & $-1,474,634$ \\
1938 & $1,650,601$ & 473,096 & $-1,177,505$ \\
1939 & $2,029,583$ & 479,930 & $-1,549,653$ \\
\hline
\end{tabular}

Source: Mizuno, 1995:162 and Yokohama Shokin Ginko Chosaka, 1940:303-4.

Table 2. Japanese raw cotton imports from Brazil, 1934-8 (thousand kilos)

\begin{tabular}{llllllr}
\hline Years & $\begin{array}{l}\text { Total } \\
\text { Brazilian } \\
\text { cotton } \\
\text { exports }\end{array}$ & $\begin{array}{l}\text { Brazilian } \\
\text { cotton } \\
\text { exports }\end{array}$ & $\begin{array}{l}\text { Total } \\
\text { to Japan }\end{array}$ & & $\begin{array}{l}\text { Japanese } \\
\text { cotton } \\
\text { imports }\end{array}$ & $\begin{array}{l}\text { Japanese } \\
\text { cotton } \\
\text { imports } \\
\text { from Brazil }\end{array}$ \\
\hline 1934 & $\mathbf{1 2 6 , 5 2 8 . 0}$ & $\mathbf{1 , 6 9 5 . 7}$ & 1.3 & $\mathbf{8 1 3 , 2 9 1 . 1}$ & $\mathbf{1 , 6 9 5 . 7}$ & 0.2 \\
1935 & $\mathbf{1 3 8 , 6 3 0 . 0}$ & $\mathbf{2 , 4 9 1 . 6}$ & 1.8 & $\mathbf{7 3 7 , 0 2 4 . 3}$ & $\mathbf{2 , 4 9 1 . 6}$ & $\mathbf{0 . 3}$ \\
1936 & $\mathbf{2 0 0 , 3 1 3 . 0}$ & $\mathbf{4 3 , 3 2 8 . 2}$ & $\mathbf{2 1 . 6}$ & $\mathbf{9 1 2 , 6 7 0 . 1}$ & $\mathbf{4 3 , 3 2 8 . 2}$ & 4.7 \\
1937 & $\mathbf{2 3 6 , 1 8 1 . 0}$ & $\mathbf{5 0 , 9 1 8 . 0}$ & $\mathbf{2 1 . 6}$ & $\mathbf{8 2 5 , 8 9 4 . 8}$ & $\mathbf{5 0 , 9 1 8 . 0}$ & $\mathbf{6 . 2}$ \\
1938 & $\mathbf{2 6 8 , 7 1 9 . 0}$ & $\mathbf{6 0 , 1 5 9 . 0}$ & $\mathbf{2 2 . 4}$ & $\mathbf{5 6 2 , 7 0 7 . 2}$ & $\mathbf{6 0 , 1 5 9 . 0}$ & $\mathbf{1 0 . 7}$ \\
\hline
\end{tabular}

Source: Yokohama Shôkin Ginkô Chôsaka, 1940:340-1.

Table 3. Japanese-American trade, 1928-1937 (current prices in thousand yen)

\begin{tabular}{lccc}
\hline Years & Japanese Exports & Japanese Imports & Exports-Imports \\
\hline 1928 & $\mathbf{8 2 6 , 1 4 1 . 1}$ & $\mathbf{6 2 5 , 5 3 6 . 4}$ & $\mathbf{2 0 0 , 6 0 4 . 7}$ \\
1929 & $\mathbf{9 1 4 , 0 8 4 . 5}$ & $\mathbf{6 5 4 , 0 6 0 . 2}$ & $\mathbf{2 6 0 , 0 2 4 . 3}$ \\
1930 & $\mathbf{5 0 6 , 2 2 0 . 1}$ & $\mathbf{4 4 2 , 8 8 2 . 5}$ & $\mathbf{6 3 , 3 3 7 . 6}$ \\
1931 & $425,330.2$ & $\mathbf{3 4 2 , 2 9 0 . 0}$ & $\mathbf{8 3 , 0 4 0 . 2}$ \\
1932 & $445,147.5$ & $\mathbf{5 0 9 , 8 7 3 . 6}$ & $\mathbf{- 6 4 , 7 2 6 . 1}$ \\
1933 & $492,237.6$ & $620,778.7$ & $\mathbf{- 1 2 8 , 5 4 1 . 1}$ \\
1934 & $\mathbf{3 9 8 , 9 2 8 . 1}$ & $\mathbf{7 6 9 , 3 5 9 . 1}$ & $\mathbf{- 3 7 0 , 4 3 1 . 0}$ \\
1935 & $\mathbf{5 3 5 , 3 8 9 . 4}$ & $\mathbf{8 0 9 , 6 4 4 . 6}$ & $\mathbf{- 2 7 4 , 2 5 5 . 2}$ \\
1936 & $\mathbf{5 9 4 , 2 5 2 . 3}$ & $\mathbf{8 4 7 , 4 9 0 . 2}$ & $\mathbf{- 2 5 3 , 2 3 7 . 9}$ \\
1937 & $\mathbf{6 3 9 , 4 2 8 . 0}$ & $\mathbf{1 , 2 6 9 , 5 4 2 . 0}$ & $\mathbf{- 6 3 0 , 1 1 4 . 0}$ \\
\hline
\end{tabular}

Source: FEAJ, various years. 
Economic explanations can also be suggested. The typical argument goes as follows. In the early 1930s, a substantial number of countries instituted limits on imports from Japan. The 1930s principle of bilaterally balanced trade caused Japan to reduce imports from these countries and to increase imports from other countries:"The necessity of balancing her trade with particular countries because of import restrictions on her goods led to a growth in imports from Africa and SouthAmerica". ${ }^{3}$ Since Japan was running a trade deficit with the United States in 1934, she reduced its imports of American raw cotton in order to try to reduce the trade deficit. There is some merit in this argument. It starts from an analysis of Japan's foreign trade in 1934. But, by itself it does not fit the reality that Japan's trade deficit with the United States remained large after 1934. (Table 3) Nor does it fit the reality that not only Japanese imports from, but also Japanese exports to, Brazil increased as a result of the mission. (Table 1)

Thus a more complete explanation is called for. This paper aims to provide such a more complete explanation. It starts from an analysis of Japan's foreign trade in 1934. It acknowledges the importance at that time to Japan of its huge trade deficit with the United States. But it argues that Japan's most important reason for organizing the trade mission to Brazil was not the intention to reduce the raw cotton imports from the United States but the hope to be able to increase exports to Brazil. But Brazil was a debtor country. Japan thus had to import from Brazil in order to be able to export to it. Brazil was at that time emerging as an important producer of raw cotton. This allowed Japan to increase its raw cotton imports from Brazil, and reduce its raw cotton imports from the United States, this being only a secondary objective. This paper also acknowledges that replacing American with Brazilian raw cotton met Japan's concern about geo-strategic control over natural resources. ${ }^{4} \mathrm{But}$ it also argues that this was certainly not the most important reason for starting to import raw cotton from Brazil.

The kind of evidences offered in this paper to support the argument

Allen, 1981: 164 .

We have to note here continuing the efforts of Japan to increase its self-suflu iency through the promotion of raw cotton cultivation in Japanese colonies and spheres of influence, and also the efforts to import raw cotton from smaller, independent producers. These efforts - before the 1930s in Korea, China, Manchuria, Peru and Brazil — and during the 1930s in Korea, China and Manchuria — are discussed at length in Nawa, 1936.

\section{I Henri Delanghe}


is in the first place quantitative. Sections one and two provide simple quantitative overviews of Japan's foreign trade in 1928 and 1934. The other sections are more qualitative. A third section, for instance, explains the reality behind the 1934 foreign trade figures. It shows that, in 1934, Japan was a country under tremendous export pressure. A following section explains which strategies Japan adopted to deal with this export pressure. A final section explains how Brazil fitted into this strategic framework. It must be emphasized that this paper is on how trade with Brazil met Japanese foreign trade objectives. It is not about how trade with Japan met Brazilian foreign trade objectives. This paper also does not provide details on Brazil's growth as a producer of raw cotton. This is already a well documented historical reality.'

\section{Japanese Foreign Trade in 1928}

This paper takes the view that Japan's decision to organize a trade mission to Brazil in 1935 and start importing large amounts of Brazilian raw cotton in 1936 was based in the first place upon the perception of her foreign trade in 1934. To understand the salient features of Japan's foreign trade in 1934, one has to compare it with the pre-depression period, say 1928 .

In 1928, Japanese foreign trade was large and growing. Exports were only 94 percent of the 1919 level, but 398 percent of the 1909-13 average. Imports were only 101 percent of the 1919 level, but 404 percent of the 1909-13 average. Japan was running a visible trade deficit as exports were only 90 percent of imports. (Table 4)

Japan's export trade consisted of semi-finished and finished goods. Raw silk was the most important semi-finished good. Cotton and silk textiles were the most important finished goods. Textile tissues, yarns and materials thereof accounted for more than 60 percent of Japan's export trade. Japan's import trade consisted of raw materials and unprocessed food products on the one hand, and manufactured goods on the other. The most important raw materials were raw cotton, wool, wood and oil. The most important manufactured goods were chemicals, machinery, metals and processed food products. (Table 5)

Most of Japan's exports were destined to North America and Asia. Europe was a distant third. Most of Japan's imports came from Asia and North America. (Table 6) The pattern of Japan's export and import

See among others Pearse, 1937; and various years of the International cotton bulletin. 
trade made the United States by far her most important trading partner, accounting for 35 percent of Japan's foreign trade in 1928. (Table 7) It took most of Japan's raw silk, as well as silk tissues, pottery, comestibles and tea. It supplied most of Japan's raw cotton, as well as wood, machinery, automobiles and oil. (Table 8) After the United States came China and British India, which accounted for 15 percent and 10 percent of Japan's foreign trade respectively. Both were important markets for Japanese cotton tissues. China further took sugar, coal, cotton yarn and aquatic products. British India further took other textile products such as silk tissues, knitted goods and cotton yarn. China supplied products such as raw cotton, oil-cake and beans and peas. India supplied products such as raw cotton, pig-iron and rubber. Somewhat less important trading partners were the Kwantung Peninsula ( 6 percent) and Great Britain (5 percent). Note that Japan at the time ran trade surpluses with both the United States and China, and trade deficits with British India, the Kwantung Peninsula and Great Britain.

\section{Japanese Foreign Trade in 1934}

The Great Depression caused Japan's foreign trade to look very different in 1934. And it was the perception of her foreign trade which propelled Japan in that year to organize a trade mission to Brazil and to start importing Brazilian raw cotton.

Exports had recovered from a 1931 minimum of 1,147 million yen, and represented 110 percent of the 1928 level. Imports had recovered from a 1931 minimum of 1,236 million yen and were at 104 percent of the 1928 level. Exports were 95 percent of imports, and Japan was still running a visible trade deficit. (Table 4)

Semi-finished goods became much less important. Dramatic falls in the price of raw silk in 1930 and 1931 caused the raw silk export trade to collapse. Raw silk accounted for only 13.2 percent of exports in 1934, compared to 37.2 percent in 1928. Finished goods became much more important. Cotton tissues exports had increased. They overtook raw silk as the most important export item. However, the combined proportion of textile tissues, yarns and materials thereof had decreased. Exports of machinery, iron and vehicles, on the other hand, had become more important. The structure of the import trade had also changed. The proportion of textile raw materials had increased significantly. But so had that of iron, oil and machinery. (Table 9)

Japan's export trade became more diversified. Asia took more Japanese

\section{I Henri Delanghe}


Table 4. Value of the foreign trade of Japan, 1919-37 (current prices in million yen)

\begin{tabular}{|c|c|c|c|c|c|}
\hline Years & Imports & Exports & Years & Imports & Exports \\
\hline $\begin{array}{l}1909- \\
1913 \text { av. }\end{array}$ & 544 & 496 & 1928 & 2,196 & 1,972 \\
\hline 1919 & 2,173 & 2,099 & 1929 & 2,216 & 2,149 \\
\hline 1920 & 2,336 & 1,948 & 1930 & 1,546 & 1,470 \\
\hline 1921 & 1,614 & 1,253 & 1931 & 1,236 & 1,147 \\
\hline 1922 & 1,890 & 1,638 & 1932 & 1,432 & 1,410 \\
\hline 1923 & 1,982 & 1,488 & 1933 & 1,917 & 1,861 \\
\hline 1924 & 2,453 & 1,807 & 1934 & 2,283 & 2,172 \\
\hline 1925 & 2,573 & 2,306 & 1935 & 2,472 & 2,499 \\
\hline 1926 & 2,377 & 2,045 & 1936 & 2,764 & 2,693 \\
\hline 1927 & 7,179 & 1,992 & 1937 & 3,783 & 3,175 \\
\hline
\end{tabular}

Source: Allen, 1981:269.

Table 5. Japan's top ten export and import products in 1928 (current prices in yen)

\begin{tabular}{lrrlrr}
\hline Products & Export value & $\%$ & Products & Import value & $\%$ \\
\hline Raw silk & $\mathbf{7 3 2 , 6 9 7 , 0 0 0}$ & $\mathbf{3 7 . 2}$ & Raw cotton & $\mathbf{5 4 9 , 6 1 2 , 0 0 0}$ & $\mathbf{2 5 . 0}$ \\
Cotton tissues & $\mathbf{3 5 2 , 2 1 7 , 0 0 0}$ & $\mathbf{1 7 . 9}$ & Wool & $\mathbf{1 1 1 , 8 5 6 , 0 0 0}$ & $\mathbf{5 . 1}$ \\
Silk tissues & $\mathbf{1 3 4 , 0 5 9 , 0 0 0}$ & $\mathbf{6 . 8}$ & Wood & $\mathbf{1 1 1 , 0 0 8 , 0 0 0}$ & $\mathbf{5 . 1}$ \\
Refined sugar & $\mathbf{3 8 , 4 1 4 , 0 0 0}$ & 1.9 & Fertilizer & $\mathbf{9 5 , 9 3 9 , 0 0 0}$ & $\mathbf{4 . 4}$ \\
Pottery & $\mathbf{3 4 , 6 4 2 , 0 0 0}$ & 1.8 & Machinery & $\mathbf{9 2 , 2 0 5 , 0 0 0}$ & $\mathbf{4 . 2}$ \\
Knitted goods & $\mathbf{3 3 , 3 0 1 , 0 0 0}$ & 1.7 & Mineral oil & $\mathbf{8 9 , 8 8 3 , 0 0 0}$ & $\mathbf{4 . 1}$ \\
Cotton yarn & $\mathbf{2 5 , 8 9 4 , 0 0 0}$ & 1.3 & Beans and peas & $\mathbf{6 7 , 8 5 7 , 0 0 0}$ & $\mathbf{3 . 1}$ \\
Paper & $\mathbf{2 5 , 6 7 2 , 0 0 0}$ & 1.3 & Wheat & $\mathbf{6 7 , 7 8 7 , 0 0 0}$ & $\mathbf{3 . 1}$ \\
Wheat flour & $\mathbf{2 4 , 7 1 8 , 0 0 0}$ & 1.3 & Sugar & $\mathbf{6 4 , 9 5 8 , 0 0 0}$ & $\mathbf{3 . 0}$ \\
Coal & $\mathbf{2 4 , 5 1 3 , 0 0 0}$ & 1.2 & Iron plate & $\mathbf{3 8 , 7 0 8 , 0 0 0}$ & 1.8 \\
\hline Total & $\mathbf{1 , 9 7 1 , 9 5 5 , 3 5 2}$ & $\mathbf{1 0 0 . 0}$ & Total & $\mathbf{2 , 1 9 6 , 3 1 4 , 7 2 7}$ & $\mathbf{1 0 0 . 0}$ \\
\hline
\end{tabular}

Source: FEAJ, 1929:155-6.

Table 6. Geographical composition of Japanese exports and imports in 1928 (\%)

\begin{tabular}{lclr}
\hline Continents & Exports & Continents & Imports \\
\hline Asia & 42.3 & Asia & 41.2 \\
Europe & 8.1 & Europe & 18.4 \\
North America & 43.6 & North America & 31.6 \\
South America & 1.1 & South America & 0.6 \\
Africa & 2.2 & Africa & 1.4 \\
Other countries & 2.7 & Other countries & 6.1 \\
\hline
\end{tabular}

Source: FEAJ, 1929:154-5. 
Table 7. Japan's top ten export destinations and sources of imports in 1928 (current prices in yen)

\begin{tabular}{lrrlrr}
\hline Countries & Exports & $\%$ & Countries & Imports & $\%$ \\
\hline USA & $\mathbf{8 2 6 , 1 4 1 , 0 9 7}$ & $\mathbf{4 1 . 9}$ & USA & $\mathbf{6 2 5 , 5 3 6 , 4 0 9}$ & $\mathbf{2 8 . 5}$ \\
China & $\mathbf{3 7 3 , 1 4 1 , 9 1 1}$ & $\mathbf{1 8 . 9}$ & British India & $\mathbf{2 8 5 , 4 6 7 , 9 7 1}$ & $\mathbf{1 3 . 0}$ \\
British India & $\mathbf{1 4 6 , 0 0 6 , 6 3 8}$ & $\mathbf{7 . 4}$ & China & $\mathbf{2 3 4 , 5 5 6 , 6 8 3}$ & $\mathbf{1 0 . 7}$ \\
Kwantung Province & $\mathbf{1 1 0 , 1 9 0 , 3 8 8}$ & $\mathbf{5 . 6}$ & Great Britain & $\mathbf{1 6 4 , 8 3 0 , 4 1 9}$ & $\mathbf{7 . 5}$ \\
Dutch India & $\mathbf{7 3 , 4 1 4 , 1 7 7}$ & $\mathbf{3 . 7}$ & Kwantung Province & $\mathbf{1 5 0 , 4 3 9 , 0 2 2}$ & $\mathbf{6 . 8}$ \\
France & $\mathbf{6 3 , 4 0 8 , 4 3 1}$ & $\mathbf{3 . 2}$ & Germany & $\mathbf{1 3 3 , 5 3 7 , 4 9 0}$ & $\mathbf{6 . 1}$ \\
Great Britain & $\mathbf{5 8 , 9 0 4 , 4 5 9}$ & $\mathbf{3 . 0}$ & Australia & $\mathbf{1 3 0 , 4 9 4 , 7 5 4}$ & $\mathbf{5 . 9}$ \\
Hongkong & $\mathbf{5 6 , 2 0 4 , 3 5 3}$ & $\mathbf{2 . 9}$ & Dutch India & $\mathbf{1 1 2 , 9 1 7 , 1 3 3}$ & $\mathbf{5 . 1}$ \\
Australia & $\mathbf{4 3 , 0 0 0 , 5 9 0}$ & $\mathbf{2 . 2}$ & Canada & $\mathbf{6 6 , 4 6 4 , 9 5 3}$ & $\mathbf{3 . 0}$ \\
Philippine Islands & $\mathbf{2 9 , 0 5 4 , 7 6 9}$ & $\mathbf{1 . 5}$ & Straits Settlement & $\mathbf{3 6 , 5 8 1 , 3 0 9}$ & $\mathbf{1 . 7}$ \\
\hline Total & $\mathbf{1 , 9 7 1 , 9 5 5 , 3 5 2}$ & $\mathbf{1 0 0 . 0}$ & Total & $\mathbf{2 , 1 9 6 , 3 1 4 , 7 2 7}$ & $\mathbf{1 0 0 . 0}$ \\
\hline
\end{tabular}

Source: FEAJ, 1929:128-131.

Table 8. Japan's top five export and import products to and from the USA in 1928 and 1934 (current prices in yen)

1928

\begin{tabular}{lrrlrr}
\hline Products & \multicolumn{1}{c}{ Exports } & $\%$ & Products & Imports & $\%$ \\
\hline Raw silk & $\mathbf{6 8 7 , 4 6 4 , 0 0 0}$ & $\mathbf{8 3 . 2}$ & Raw cotton & $\mathbf{2 4 5 , 9 2 6 , 0 0 0}$ & $\mathbf{3 9 . 3}$ \\
Silk tissues & $15,407,000$ & 1.9 & Wood & $\mathbf{8 4 , 9 2 7 , 0 0 0}$ & $\mathbf{1 3 . 6}$ \\
Pottery & $13,793,000$ & 1.7 & Machinery/parts & $\mathbf{3 0 , 0 4 6 , 0 0 0}$ & 4.8 \\
Comestibles & & & & & \\
$\quad$ (tin \& bottle) & $\mathbf{1 1 , 2 8 5 , 0 0 0}$ & 1.4 & Automobiles & $\mathbf{2 9 , 3 5 4 , 0 0 0}$ & 4.7 \\
Tea & $\mathbf{9 , 2 8 8 , 0 0 0}$ & 1.1 & Kerosene oil & $\mathbf{1 4 , 9 6 5 , 0 0 0}$ & $\mathbf{2 . 4}$ \\
\hline Total & $\mathbf{8 2 6 , 1 4 1 , 0 9 7}$ & $\mathbf{1 0 0 . 0}$ & Total & $\mathbf{6 2 5 , 5 3 6 , 4 0 9}$ & $\mathbf{1 0 0 . 0}$ \\
\hline
\end{tabular}

Source: FEAJ, 1929:140-7.

1934

\begin{tabular}{lrrlrr}
\hline Products & \multicolumn{1}{l}{ Exports } & $\%$ & Products & Imports & $\%$ \\
\hline Raw silk & $\mathbf{2 3 9 , 5 6 8 , 0 0 0}$ & $\mathbf{6 0 . 1}$ & Raw cotton & $\mathbf{4 0 0 , 9 1 8 , 0 0 0}$ & $\mathbf{6 4 . 1}$ \\
Pottery & $\mathbf{1 4 , 3 1 3 , 0 0 0}$ & $\mathbf{3 . 6}$ & Machinery/parts & $\mathbf{3 5 , 1 3 7 , 0 0 0}$ & 5.6 \\
Comestibles & & & & & \\
$\quad$ (tin \& bottle) & $\mathbf{1 1 , 1 8 2 , 0 0 0}$ & 2.8 & Automobiles/parts & $\mathbf{3 1 , 5 5 3 , 0 0 0}$ & 5.0 \\
(Artificial) silk tissues & $\mathbf{5 , 5 4 0 , 0 0 0}$ & 1.4 & Wood & $\mathbf{2 0 , 9 6 6 , 0 0 0}$ & 3.4 \\
Plaits for hat making & $\mathbf{4 , 9 4 6 , 0 0 0}$ & 1.2 & Pulp & $\mathbf{1 6 , 3 2 1 , 0 0 0}$ & $\mathbf{2 . 6}$ \\
\hline Total & $\mathbf{3 9 8 , 9 2 8 , 1 3 9}$ & $\mathbf{1 0 0 . 0}$ & Total & $\mathbf{7 6 9 , 3 5 9 , 0 0 0}$ & $\mathbf{1 0 0 . 0}$ \\
\hline
\end{tabular}

Source: FEAJ, 1935:138-145. 
exports, and so did other peripheral areas. The export trade with Europe slightly increased, while that with North America collapsed. North America provided more imports and so did several peripheral areas. Both Asia and Europe provided less imports. (Table 10) The pattern of Japan's foreign trade maintained the United States as the most important trading partner ( 26 percent), followed by China (12 percent) and British India plus Ceylon (11 percent). More important than before were Australia (6 percent) and Dutch East India (5 percent). Note that, with the exception of Dutch East India, Japan ran trade deficits with all those countries. Her two largest trading partners, the United States and China, had turned from trade-surplus to trade-deficit countries. The trade deficit with the United States was becoming quite alarming. (Table 11)

\section{Japan Under Export Pressure}

In 1934 , Japan was a country under tremendous export pressure. ${ }^{6}$ It became ever more difficult for Japan to pay for her imports. On the one hand, there was the fact that Japan could not easily reduce, and even had to increase, its imports. In 1931, Japan had embarked on a policy of reflation through industrialization and militarization. ${ }^{7}$ Thus Japan could not easily reduce its imports of industrial raw materials and machinery. On the other hand, there was the above-mentioned collapse of its main export trade, the silk trade. This trade did not affect negatively Japan's overall trade balance because Japan itself produced silk. But the export trade which is supposed to replace the silk trade, the cotton tissues trade, was dependent for all its raw materials on imports, and thus negatively affected Japan's overall trade balance.

On the other hand, it became ever more difficult for Japan to pay for these necessary imports. The fall in the value of the yen after December 1931, when Japan left the gold standard, made Japanese exports cheaper and foreign imports more expensive. The value of the yen was allowed to fall from 49.85 dollars/100 yen in December 1931, to 20.70 dollars in December 1932. It then went up again to 30.25 dollars in December 1933, remaining stable and linked to the pound for the next five years. ${ }^{8}$

Specifically about Japan as a country under export pressure see Ishii, 1995.

Allen, 1981: 141.

Idem, 143. 
Worsening terms of trade also made it ever harder to pay for imports. Taking 1928 as 100 , they fell to 88 in 1932,69 in 1936 and 60 in $1937 .{ }^{\circ}$

A particularly important problem affecting japan's capacity to import was its huge trade deficit with the United States. It was clear that Japan ran a huge trade deficit with the United States in 1934. Japanese exports to the United States decreased from 826.1 million yen in 1928 to 398.9 million yen in 1934. Japanese imports from the United States increased from 625.5 million yen in 1928 to 769.4 million yen in 1934 . A trade surplus of 200.6 million yen in 1928 thus turned into a trade deficit of 370.4 million yen in 1934. (Tables 7 and 11)

On the other hand, Japan could not easily reduce her traditional imports of certain industrial raw materials and machinery. But Japan also imported growing amounts of American raw cotton. The growth of the import-dependent Japanese cotton textile industry called for ever larger imports of raw cotton. Trade frictions with British India and the absence of suitable alternative suppliers increased Japan's dependence on the United States for its raw cotton imports. ${ }^{10}$ On the export side, there was the collapse of the silk trade, mainly held with the United States. This coincided with the inability of Japan to develop an export market for alternative products in the United States. Some Japanese products did not match the American needs. The United States were self-sufficient in cotton tissues, Japan's new main export item. They accounted for 249,000 yen in 1928 (0.03 percent of exports to the United States), and 2,763,000 yen in 1934 (0.7 percent of exports to the United States). And Japan did find just a little more takers for her machinery and other products. Exports other than raw silk increased from 138.7 million yen to 159.4 million yen. Other Japanese products matched the requirements of American market but were held back by protectionist measures. In 1934, for the first time, Japan had to limit voluntarily her exports of cotton carpets and pencils. 11

This trade deficit with the United States was perceived to be problematic and contrary to the 1930s' idea that trade should be bilaterally balanced. At the same time, there was the reality that an increasing proportion of exports went to colonies and areas of influence,

Idem, 145 .

- Combined with the fall in the value of the yen and worsening terms of trade this also meant that Japan had to produce its cotton tissues ever more efficiently.

FEAJ, 1935: 152 .

\section{I Henri Delanghe}


Table 9. Japan's top ten export and import products in 1934 (current prices in yen)

\begin{tabular}{lrrlrr}
\hline Products & Exports & $\%$ & Products & Imports & $\%$ \\
\hline Cotton tissues & $\mathbf{4 9 2 , 3 5 1 , 0 0 0}$ & $\mathbf{2 2 . 7}$ & Raw cotton & $\mathbf{7 3 1 , 4 2 5 , 0 0 0}$ & $\mathbf{3 2 . 0}$ \\
Raw silk & $\mathbf{2 8 6 , 7 9 4 , 0 0 0}$ & $\mathbf{1 3 . 2}$ & Wool & $\mathbf{1 8 6 , 4 5 5 , 0 0 0}$ & $\mathbf{8 . 2}$ \\
Rayon tissues & $\mathbf{1 1 3 , 4 8 4 , 0 0 0}$ & $\mathbf{5 . 2}$ & Iron & $\mathbf{1 7 1 , 5 6 3 , 0 0 0}$ & $\mathbf{7 . 5}$ \\
Silk tissues & $\mathbf{7 7 , 4 8 8 , 0 0 0}$ & $\mathbf{3 . 6}$ & Mineral oil & $\mathbf{1 2 4 , 0 2 7 , 0 0 0}$ & $\mathbf{5 . 4}$ \\
Machinery/parts & $\mathbf{5 7 , 7 7 7 , 0 0 0}$ & 2.7 & Machinery & $\mathbf{9 8 , 0 2 2 , 0 0 0}$ & $\mathbf{4 . 3}$ \\
Iron & $\mathbf{5 3 , 0 2 9 , 0 0 0}$ & $\mathbf{2 . 4}$ & Gum and & & \\
Comestibles & & & gum resins & $\mathbf{6 5 , 9 8 6 , 0 0 0}$ & $\mathbf{2 . 9}$ \\
\multicolumn{1}{c}{$($ tin \& bottle) } & $\mathbf{5 0 , 3 0 4 , 0 0 0}$ & $\mathbf{2 . 3}$ & Beans and peas & $\mathbf{5 1 , 9 6 8 , 0 0 0}$ & $\mathbf{2 . 3}$ \\
Knitted goods & $\mathbf{4 7 , 6 1 8 , 0 0 0}$ & $\mathbf{2 . 2}$ & Coal & $\mathbf{4 7 , 1 9 3 , 0 0 0}$ & $\mathbf{2 . 1}$ \\
Vehicles/parts & $\mathbf{4 6 , 5 9 0 , 0 0 0}$ & $\mathbf{2 . 1}$ & Pulp & $\mathbf{4 4 , 2 5 6 , 0 0 0}$ & $\mathbf{1 . 9}$ \\
Pottery & $\mathbf{4 1 , 8 7 7 , 0 0 0}$ & $\mathbf{1 . 9}$ & Oil cake & $\mathbf{4 2 , 0 5 2 , 0 0 0}$ & $\mathbf{1 . 8}$ \\
\hline Total & $\mathbf{2 , 1 7 1 , 9 2 4 , 6 2 3}$ & $\mathbf{1 0 0 . 0}$ & & $\mathbf{2 , 2 8 2 , 6 0 1 , 6 0 0}$ & $\mathbf{1 0 0 . 0}$ \\
\hline
\end{tabular}

Source: FEAJ, 1935:153-5.

Table 10. Geographical composition of japanese exports and imports in 1934 (\%)

\begin{tabular}{lclc}
\hline Continents & Exports & Continents & Imports \\
\hline Asia & $\mathbf{5 3 . 8}$ & Asia & 35.6 \\
Europe & 10.5 & Europe & 13.0 \\
North America & 18.8 & North America & 36.1 \\
Central America & 2.0 & Central America & $\mathbf{0 . 0}$ \\
South America & 2.8 & South America & 1.0 \\
Africa & 8.4 & Africa & 3.5 \\
Oceania & 3.7 & Oceania & 9.4 \\
\hline
\end{tabular}

Source: FEAJ, 1935:154-5.

Table 11. Top ten export destinations and sources of imports in 1934 (current prices in yen)

\begin{tabular}{lrrlrr}
\hline Countries & \multicolumn{1}{l}{ Exports } & $\%$ & Countries & Imports & $\%$ \\
\hline USA & $\mathbf{3 9 8 , 9 2 8 , 1 3 9}$ & $\mathbf{1 8 . 4}$ & USA & $\mathbf{7 6 9 , 3 5 9 , 0 9 9}$ & $\mathbf{3 3 . 7}$ \\
Kwantung & $\mathbf{2 9 5 , 8 6 8 , 1 9 0}$ & $\mathbf{1 3 . 6}$ & British India+Ceylon & $\mathbf{2 9 1 , 9 5 9 , 5 8 3}$ & $\mathbf{1 2 . 8}$ \\
British India+Ceylon & $\mathbf{2 5 8 , 0 1 2 , 3 0 0}$ & $\mathbf{1 1 . 9}$ & China+Manchoukuo & $\mathbf{2 8 3 , 7 8 4 , 9 8 5}$ & $\mathbf{1 2 . 4}$ \\
China+Manchoukuo & $\mathbf{2 2 4 , 2 1 3 , 8 6 2}$ & $\mathbf{1 0 . 3}$ & Australia & $\mathbf{1 9 7 , 7 5 7 , 8 4 4}$ & $\mathbf{8 . 7}$ \\
Dutch India & $\mathbf{1 5 8 , 4 5 0 , 5 2 5}$ & 7.3 & Germany & $\mathbf{1 0 9 , 5 8 3 , 7 2 3}$ & 4.8 \\
Great Britain & $\mathbf{1 0 9 , 2 6 9 , 6 4 2}$ & 5.0 & Great Britain & $\mathbf{7 0 , 0 3 6 , 9 5 5}$ & $\mathbf{3 . 1}$ \\
Egypt & $\mathbf{7 2 , 9 8 8 , 2 5 5}$ & $\mathbf{3 . 4}$ & Dutch India & $\mathbf{6 3 , 4 6 4 , 0 6 8}$ & $\mathbf{2 . 8}$ \\
Australia & $\mathbf{6 4 , 4 6 1 , 8 6 5}$ & $\mathbf{3 . 0}$ & Straits Settlement & $\mathbf{6 3 , 3 2 0 , 2 8 1}$ & $\mathbf{2 . 8}$ \\
Straits Settlement & $\mathbf{6 3 , 3 2 0 , 1 6 1}$ & $\mathbf{2 . 9}$ & Canada & $\mathbf{5 4 , 0 9 3 , 6 2 0}$ & $\mathbf{2 . 4}$ \\
France & $\mathbf{3 8 , 3 1 8 , 5 8 9}$ & 1.8 & Egypt & $\mathbf{4 6 , 2 5 9 , 4 2 3}$ & $\mathbf{2 . 0}$ \\
\hline Total & $\mathbf{2 , 1 7 1 , 9 2 4 , 6 2 3}$ & $\mathbf{1 0 0 . 0}$ & Total & $\mathbf{2 , 2 8 2 , 6 0 1 , 6 0 0}$ & $\mathbf{1 0 0 . 0}$ \\
\hline
\end{tabular}

Source: FEAJ, 1935:127-9. 
which operated in yen, something that made it ever harder to earn the foreign exchanged to import from the United States and other markets. We have sufficient written evidence that there was a negative pen option in Japan on the trade deficit with the United States. Just one example is the justification provided for the Japanese boycott of Indian raw cotton in 1933:

"No doubt the price of American cotton is somewhat dearer than Indian cotton, and therefore the replacement of the latter with the former material means more expense for the country's cotton industry... (but)... purchase by Japan of a vast amount of cotton from America is bound to stimulate American purchase of Japanese raw silk, which is so important to the economic welfare of Japan. This will, in turn, help greatly to stabilise the exchange between the United States and Japan." 12

Another factor affecting Japan's capacity to earn the value of its imports was her inability to maintain or increase exports to traditional markets other than the United States. One reason can be found in political problems. In 1928, Japan ran a trade surplus with China (then including the not yet existing Manchoukuo). But even at that time political problems, for instance a number of Chinese boycotts against Japanese goods, were leading to a decrease of Japanese exports to China. After 1931, the drop in Japanese exports to China proper was not compensated for by the increase in exports to the Japanese puppet state Manchoukuo. This resulted in a trade deficit. Another reason was protectionism. Countries no longer did balance their imports and exports in a general manner, compensating trade deficits with one country by trade surpluses with other countries. They balanced trade bilaterally, imports from a particular country having to be balanced with exports to that same country.

Protectionism was particularly heavy against low priced Japanese cotton goods, then Japan's main export item. The volume of Japanese cotton cloth exports increased from 1,791 million square yards in 1929 to 2,710 million square yards in 1936 - an expansion of 51.3 percent. The value of japanese cotton cloth exports augmented from 413 million

12 "Japanese boycott of Indian cotton", 751. See also "Le coton (les achats en 193536)" and "Les importations de coton américain". 
yen in 1929 to 484 million yen in 1936 - a much smaller increase of 17.2 percent. This caused resentment in a number of countries, triggered by the post-1931 fall in the value of the yen and the suspicion of unjustified low wages and thus social dumping by Japan. Since Great Britain was the main victim of her trade expansion, it was mostly that country which implemented and requested trade restrictions against Japanese goods.'

Great Britain itself implemented in 1932 an Import Duties Act. While it offered free entry to goods from her dependent Empire and, for the time being, from the Dominions, she imposed duties on foreign goods. To protect her own textile industry, Great Britain next aimed to extend protectionist measures to her colonies, but it is not allowed to do this in British East Africa. This area was covered by the Convention of St. Germain (1919) which guaranteed economic equality to all the signataries and state members of the League of Nations in certain parts of Africa, mostly in the Congo Basin. Nor was it allowed to do this in its League of Nations class A (Palestine, Transjordan and Iraq) and class B (Tanganyika, British Togo and British Cameroons) mandated territories. But it was allowed to do it everywhere else. Thus protectionist measures were extended to the British colonies in 1934. On May 7 of that year, quotas on foreign cotton and rayon goods were instituted in the British West Indies and in the British Mediterranean and Asian colonies. Only excluded from these measures were some important international ports - Aden, Gibraltar and Hongkong — and some small and unimportant colonies - like St. Helena, Tonga and the Falkland Islands. On May 17 of that same year, quotas specifically on Japanese goods were also instituted in British West Africa. That was interesting because it showed that Britain was prepared to violate unilaterally her commercial agreements with Japan. Since 1898, British West Africa had been covered by the Anglo-French Convention which stated that Great Britain and France would not discriminate against each other in tariff matters in their respective colonies in West Africa, and later, Great Britain extended the open-door principle to other countries with whom she concludes commercial treaties on a most favoured nation basis. And thus, through the Anglo-Japanese Commercial Treaty of 1911, she had no right to institute quotas. Even so, as a result of such measures quotas were instituted at the end of 1934 for the

The following section is based on Shimizu, 1986 and Ampiah, 1990. 
Somaliland Protectorate, Gambia, Gold Coast, Nigeria, Sierra Leone, Cyprus, Malta, Ceylon, Malaya and Sarawak, Mauritius, Barbados, Jamaica, Leeward Island, Trinidad and Tobago, Fiji, Windward Island, British Guyana, British Honduras and the Seychelles. As a result, Japanese competition in these areas was effectively stopped. Japanese cotton piece goods exports to these areas dropped from 157.7 million yards in 1933 to 35.5 million yards in 1935 .

Great Britain also tried to extend protectionist measures to the Dominions and India. At the Ottawa Conference (1932), she concluded a number of bilateral agreements with the Dominions hindering Japanese exports. ${ }^{14}$ But, as a market for Japanese goods, India was of much greater importance than the British colonies or the dominions. India alone accounted for 26.4 percent of the value of Japanese cotton piece goods exports in 1929. This is why Lancashire firms were eager for India to discriminate against Japanese cotton piece goods. In 1930, India imposed a 15 percent duty on British goods but a 20 percent duty on foreign ones. In 1932, it imposed a 25 percent duty on British goods but a 50 percent duty on foreign ones. In March 1933, India abrogated the 1904 Indo-Japanese Commercial Convention and informed Japan of this in April 1933 with six months notice. At the same time, it imposed a 75 percent duty on foreign goods. This was more than the Japanese spinners were willing to take. While India accounted for 27.9 percent of the value of Japanese cotton piece goods exports in 1932, this dropped to 18.6 percent in 1933 and to 15.1 percent in 1934 . In reaction, the Japanese spinners started a boycott of Indian raw cotton in June 1933. After extended negotiations, an agreement was signed in April 1934 putting a maximum quota on Japanese exports to India. Thus Japanese trade became constrained in British colonies and India, and to a lesser extent in the British dominions.

But Britain also tried to affect the outcome in other areas, which were neither colonies nor dominions. In the Middle East, for instance, partially due to of British pressure, Egypt imposed largely ineffective duties on Japanese cotton piece goods in 1933, and prohibitive duties in 1935, after which Japanese exports to that country collapsed. ${ }^{15}$ Another important market were the Dutch East Indies. In 1929, they accounted for 10.2 percent of the value of Japanese cotton piece goods exports. In

Shimizu, 1986: 45.

Idem, 45 and 99.

\section{I Henri Delanghe}


1934, after Japanese-Dutch commercial talks and the institution of quotas, they were limited. ${ }^{16}$ Nevertheless, they still accounted for 16.8 percent of the value of Japanese cotton piece goods exports in $1934 .^{17}$

As a result of all the above, in 1934, the pattern of Japanese foreign trade had become more complex. Export markets became more diversified. The top five export markets accounted for 77.5 percent of exports in 1928, and only 61.5 percent in 1934. Sources of imports did become more concentrated. The top five sources ofimports accounted for 66.5 percent of imports in 1928, and 72.4 percent in 1934. The concentration of export products had decreased. The top five export products accounted for 65.6 percent of exports in 1928, compared to 47.4 percent in 1934 . The concentration of import products had increased.The top five import products accounted for 43.8 percent of imports in 1928, compared to 57.4 percent in 1934 .

Japan had to export more products to more markets, while importing less products from fewer markets. Export markets did not match sources of imports. Without any prospect of being able to increase her exports to the United States and other traditional markets Japan had to search for other ways in order to maintain the status quo in these traditional markets, and for finding new export markets, while reducing the trade deficit with the United States.

\section{Coping with New Strategies}

How did then Japan react to these various export constraints? The decision to start importing large amounts of Brazilian cotton has to be seen as part of an effort to overcome all these constraints. For this $\mathrm{j}$ a pan pursued three complementary strategies. First, it tried to avoid giving rise to protectionist feelings in traditional and new export destinations. Second, it retaliated against protectionism. Third, it looked for new markets.

A first important strategy was trying to avoid giving rise to protectionism. The Japanese government attempted to reduce the possibility of further trade frictions developing in existing or in new markets. The tool was a domestic regulation aimed at softening competition among Japanese manufacturing and export firms. Article

Idem, 53.

Idem, 53. 
2 of the 1931 Major Industries Control Law stipulated that the Government had the right to order firms which were not members of an existing cartel to conform with cartel decisions, either when two thirds of cartel members requested them to do so, or when the Government thought it necessary to protect reasonable profits within the industry and to ensure adequate development of the national economy. ${ }^{18}$ And the 1933 Export Control Law declared:

"Government intends to exert some control over exports of certain commodities, as the competition among domestic manufacturers last year and the large exports of some products resulted in unfavorable action by some foreign countries with reference to imports of Japanese goods." 19

1934 trade legislation strengthend earlier legislation by providing Government with the right to make membership of an export guild or association obligatory, in order to exercise control over export product quality, and to avoid excessive competition among Japanese exporters in foreign markets. It provided Government with full control over foreign trade, through the right to limit or prohibit exports or imports of certain goods, and also set prices for certain goods.

The second strategy was to retaliate. The 1934 legislation included for the first time a retaliative component, providing Government with the right to change import tariffs at any time. ${ }^{20}$

A third strategy was to look for new markets. In 1930, the Japanese Government aimed to increase exports to not yet constrained industrialized and non-industrialized export markets through an Export Subsidy Law, which provided for special financial assistance to firms selling in North and South America, Russia, Africa and parts of Asia. ${ }^{21}$ Efforts to the contrary notwithstanding, trade with most industrialized countries had become constrained in 1934 , so that Japan was obliged to redouble her efforts to develop new, non-industrialized export markets through a 'new country policy':

\footnotetext{
${ }^{18}$ Nakamura, 1994: 45.

19 "Japan", 619.

${ }^{20}$ "La politique d'expansion commerciale", 15-6 and "L'orientation de la politique commerciale", 17-8.

${ }^{21}$ Howe, 1996: 174.
} 
"As for the new countries, not or barely familiar with Japanese products, Japan will make an effort to buy their natural resources to the extent that they will buy its products, and this with the purpose of turning them into loyal clients. This policy will be applied particularly to the whole of Africa, Central and South America, China, India, Siam, the Straits Settlements and the Near Orient." 22

\section{Brazil, the New Country Policy and the Trade Deficit with the United States}

As a result of her new country policy, Japan sent out missions to many countries from 1934 onwards. One of the markets which Japan was eager to explore was Brazil, a rapidly developing country with a large and growing population to which Japan up to then hardly did export anything. (Table 1) There was however a problem of Brazil being a debtor country, and Japan thus having to buy in order to be able to export. Luckily, Brazil was just then becoming again an important producer of raw cotton of equal quality to, and lower price than, American cotton. By importing it, Japan could hope to increase her exports to Brazil while, at the same time, reducing the trade deficit with the United States. This would enable Japan to concentrate its trade with the United States on industrial raw materials and machinery elsewhere not available.

This reasoning behind the decision to mount a trade mission to Brazil and start importing large amounts of cotton from there is supported by ample written evidence. It is inter alia reflected in a statement made by the leader of the mission, Hirao Hachisaburo, during a farewell lunch organized for members of the economic mission by the Osaka textile community in March 1935. ${ }^{23}$ Hirao remarked there that Japanese-Brazilian relations had started more than forty years earlier, and that the first Japanese migrants had arrived in Brazil 25 years before. Even so Japanese-Brazilian trade remained insignificant.The reason for this was that Japan had been thinking of Brazil only as a country to send migrants to, and not as a country to develop trade with. Nevertheless - he said - Brazil is big, not densely populated, and rich in natural resources.Therefore, it was quite natural that Brazil, the country with

$22 \quad$ Translated from French. "La politique d'expansion commerciale", 16.

"Ken-haku keizai shisetsudan sobetsu goshokkai", 18-22. 
the potential of becoming the biggest agricultural producer, and Japan, striving to become the world's most advanced industrial country should develop trade relations. The problem before was that Brazil only grew coffee, a commodity not consumed in large quantities by Japan. And also that Brazil, being a debtor country, could only buy products from countries which bought its coffee. As a result of this, small countries had more trade with Brazil than Japan. However, coffee production and trade had now collapsed, and a move towards other crops was going on. Because of physical conditions, none was as successful as cotton, precisely the commodity of which Japan needed large quantities.

\section{Main Conclusions}

This paper has argued that to understand why Japan started importing large amounts of raw cotton from Brazil in 1936 one has to analyze Japan's foreign trade in 1934. On the basis of quantitative and qualitative evidence, this paper has argued that in $1934 \mathrm{Japan}$ was a country under tremendous export pressure. On the one hand because of a policy of reflation through industrialization and militarization, and due to the growth of the import-dependent cotton textile industry, Japan would not easily reduce her imports. On the other hand, the post-1931 yen devaluation, the worsening terms of trade, the trade deficit with the United States and the growing worldwide protectionism against Japanese goods made it more and more difficult to earn the foreign exchange necessary to pay for the necessary imports.

One of the strategies Japan adopted then to overcome this obstacle was to explore new markets. Brazil was at the time attractive as a large and growing market with which trade was then almost non-existing. Brazil, however, was a debtor country, so that Japan had to buy first in order to be able to export. Brazil was just then emerging again as an important producer of raw cotton, a much needed raw material for Japan's cotton textile industry. As a secondary objective, growing imports of raw cotton from Brazil could allow Japan partially to relieve its trade deficit with the United States.

\section{Bibliographical References}

Allen, G. C. A Short Economic History of Modern Japan. 4th edition. London and Basingstoke: The Macmillan Press Ltd., 1981.

Ampiah, K. "British commercial policies against Japanese expansionism in East and 
West Africa, 1932-1935": International Journal of African Historical Studies, 23 (4), p. 619-641, 1990.

Beasley, W. G. The Rise of Modern Japan. New York: St. Martin's Press, 1990. .Japanese Imperialism 1894-1945. Oxford: Clarendon Press, 1994.

Drummond, I. A. British Economic Policy and the Empire 1919-1939. London: George Allen and Unwin Ltd., 1972.

Department of Finance. Financial and Economic Annual of Japan 1929. s.1.: Government Printing Office, s.d. (FEAJ). s.d. (FEAJ).

Howe, C. The Origins of Japanese Trade Supremacy. Development and Technology in Asia from 1540 to the Pacific War. London: Hurst and Company, 1996.

Ishii, O. Sekai kyoko to nihon no "keizai gaiko" - 1930-1936nen (The World Depression and Japan's Economic Diplomacy - 1930-6). Tokyo: Keisô Shobô, 1995.

"Japan": International Cotton Bulletin, 44 (XI/4), 618-619, Jul-Aug. 1933.

"Japanese boycott of Indian cotton": International Cotton Bulletin, 44 (XI/4), p. 750751, Jul-Aug. 1933.

"Ken-haku keizai shisetsudan sobetsu goshokkai" (Farewell luncheon meeting for the economic mission to Brazil), in: Dai Nihon Bôseki Rengôkai Geppô (Monthly of the All Japan Spinners'Association), 511, p. 18-22, Apr. 1935.

"La politique d'expansion commerciale": Bulletin d'Informations Économiques et Financières Japonaises, IX/30, p. 15-16, Mar. 1934.

"Le coton (les achats en 1935-36)": Bulletin d'Informations Économiques et Financières Japonaises, XI/41, p. 14-15, Dec. 1936.

"Le Japon et le Bresil": Bulletin d'Informations Économiques et Financières Japonaises, X/ 36, p. 15-16, Sep. 1935.

"Les importations de coton americain": Bulletin d'lnformations Économiques et Financières Japonaises, XII/43, p. 20, Jun. 1937.

Lockwood, W. W. The Economic Development of Japan. Growth and Structural Change 1868-1938. Princeton, N. J.: Princeton University Press, 1954.

"L'orientation de la politique commerciale": Bulletin d'lnformations Économiques et Financières Japonaises, IX/31, p. 17-18, Jun. 1934.

Nakamura,T. Lectures on Modern Japanese Economic History 1926-1994.Tokyo: University of Tokyo Press, 1994.

Nawa,T."The Cotton Spinning Industry and the Problems of Raw Cotton", reprinted from the Journal of the Osaka University of Commerce, IV, December 1936.

Pearse, A. S. Cotton Progress in Brazil. Manchester: International Federation of Master Cotton Spinners' and Manufacturers' Associations, 1937.

Saito, H. "Brazil and Japan": Kodansha Encyclopedia of Japan.Vol. I. Tokyo and New York: Kodansha, p. 167-169, 1983.

Shimizu, H. Anglo-Japanese Trade Rivalry in the Middle East in tire Inter-War Period. London: Ithaca Press, 1986.

"Spinning and textile industries": Japan-Manchoukuo Yearbook 1931, p. 415-419. 